\title{
RESULTS OF AN AERIAL SURVEY OF THE WESTERN POPULATION OF ANSER ERYTHROPUS (ANSERINI) IN AUTUMN MIGRATION IN RUSSIA 2017
}

\author{
Sofia B. Rozenfeld ${ }^{1,2, *}$, George V. Kirtaev³, Natalya V. Rogova ${ }^{3, * *}$, Mikhail Yu. Soloviev ${ }^{4, * * *}$ \\ ${ }^{1} A . N$. Severtsov Institute of Ecology and Evolution of RAS, Russia \\ *e-mail: rozenfeldbro@mail.ru \\ ${ }^{2}$ State Nature Reserve "Gydansky», Russia \\ ${ }^{3}$ Goose, Swan and Duck Study Group of Northern Eurasia, Russia \\ **e-mail:nrogova@gmail.com \\ ${ }^{4}$ Lomonosov Moscow State University, Russia \\ ***e-mail:mikhail-soloviev@yandex.ru
}

Received: 11.07.2018. Revised: 05.11.2018. Accepted: 13.11.2018.

\begin{abstract}
The global population of Anser erythropus has rapidly declined since the middle of the $20^{\text {th }}$ century. The decline in numbers has been accompanied by the fragmentation of the breeding range and is considered as «continuing affecting all populations, giving rise to fears that the species may go extinct». Overhunting, poaching and habitat loss are considered to be the main threats. The official estimate of the dimension of the decline is in the range of $30 \%$ to $49 \%$ between 1998 and 2008. Monitoring and the prospection of new areas are needed for the future conservation of this species. The eastern part of the Nenetsky Autonomous Okrug, the Baydaratskaya Bay and the Lower Ob (Dvuobye) are important territories for the Western main population of Anser erythropus on a flyway scale. Moving along the coast to the east, Anser erythropus can stay for a long time on the Barents Sea Coast, from where they fly over the Baydaratskaya Bay to the Dvuobye. We made aerial surveys and identified key sites and the main threats for Anser erythropus on this part of the flyway. According to our data, the numbers of the Western main population of Anser erythropus amount to $48580 \pm 2820$ individuals after the breeding season, i.e. higher than the previous estimates made in autumn in Northern Kazakhstan. The key sites of Anser erythropus in this part of the flyway were identified.
\end{abstract}

Key words: aerial counts, Lesser White-fronted Goose, monitoring, Nenetsky Autonomous Okrug, YamaloNenetsky Autonomous Okrug

\section{Introduction}

Anser erythropus Linnaeus, 1758 is the smallest of the geese in the genus Anser. The species is globally threatened, being recognised as Vulnerable by IUCN - The World Conservation Union (IUCN, 2006). This species ranked by BirdLife International as 'SPEC 1' within Europe, denoting a European species of global conservation concern (BirdLife International, 2004). It is listed in Annex 1 of the European Council Directive of April 21979 on the conservation of wild birds (79/409/ EEC), in Column A of the Action Plan under the African-Eurasian Migratory Waterbird Agreement (AEWA) and in Annex II «Strictly protected species») of the Bern Convention. This species is listed in the Red Data Book of Russia (Vinogradov \& Morozov, 2001) as a rare species (category 2). Anser erythropus is a long-distance Palearctic migrant, currently breeding discontinuously in the sub-arctic zone from northern Fennoscandia to eastern Siberia. Four subpopulations can be recognised, three of which are surviving components of the species' formerly more extensive breeding range. These are the Fennoscandian population (breeding in the Nordic countries and the Kola
Peninsula, northwesternmost Russia); the Western main population (nesting in northern Russia west of the Taimyr Peninsula); the Asian main population (nesting in the eastern Taimyr Peninsula and wintering in China). The global population of $A n-$ ser erythropus has rapidly declined since the middle of the $20^{\text {th }}$ century. The official estimate of the dimension of the decline is in the range of $30 \%$ to 49\% between 1998 and 2008 (Jones et al., 2008). The current estimate of the Western main population size is 30000 (Fox \& Leafloor, 2018) - 34000 (Cuthbert \& Aarvak, 2016) individuals.

Thus, monitoring and the prospection of new areas could be extremely useful for the assessment of the current numbers and state of Anser erythropus for the future conservation of this species. The objective of the present work is, using the most effective methods, to estimate the numbers and status of the Western main population in the key regions during the autumn migration. These data could be used for conservation on an international scale. As hunting is deemed one of the most negative factors for the species, a large-scale survey would allow for the creation of hunting free zones at the key sites revealed. 
It is clear that in vast, inaccessible areas, the monitoring and counts of migratory birds can be processed only by using aviation. In North America, waterfowl are typically surveyed by aerial surveys. The Migratory Bird Treaty Act (1918) requires signatory countries to establish hunting regulations that ensure sustainability of bird populations while affording harvest opportunities for subsistence and sport hunters. Experimental efforts at surveying waterfowl were initiated since 1930 (Bowman, 2014). To assess status of bird populations the U.S. Fish and Wildlife Service began developing methods for aerial surveys in the mid-1940s. By 1955, a continent-wide waterfowl breeding population survey was operational in North America. Methods for this survey, known as the Waterfowl Breeding Population and Habitat Survey (WBPHS) were formalised in a protocol document written jointly between the U.S. Fish and Wildlife Service and the Canadian Wildlife Service in 1987 (Platte, 1987). The WBPHS survey was the seed for numerous additional aerial surveys that focus on specific management questions and conservation efforts (Baldassarre \& Bolen, 2006; Kerbes et al., 2009). Within harvest management processes, specific population size benchmarks have been identified that trigger different harvest strategies. Measuring status relative to those benchmarks is accomplished with aerial surveys (U.S. Fish \& Wildlife Service, 2012). In the US Waterfowl Program currently uses the light aircrafts on amphibious floats. This airframe is ideal for long-range flights over variable terrain and conditions. Amphibious floats provide a combination of safety for operations beyond gliding distance from the shore and the flexibility to operate on water or runways (Aerial Survey Training Manual U.S. Fish \& Wildlife Service Migratory Bird Management, Alaska Region, 2016).

In the Soviet Union large aircrafts, such as AN-2 or MI-8, were used. Theses types of aircrafts significantly limit the possibility of observations and bird counts and are very expensive. Unfortunately, at present, the methods of aerial surveys and monitoring existing in Russia are hopelessly outdated. There are no approved methods for aerial surveys of migratory birds in Russia. Monitoring of their populations at the state level is not carried out. This leads to a not sustainable use of waterfowl resources and the lack of effectiveness of measures for their conservation. With the development of light and ultra light aviation, entirely new prospects opened up. It became necessary to develop new methods of aerial surveys using the experience of North American countries, including those used in the 1990s (Poyarkov et al., 2000). Based on North American experience, we used ultra-light aircraft on floats for the counts.

The flyway of Anser erythropus is very large. Anser erythropus nesting in the Nenetsky Autonomous Okrug (NAO) moves along the Barents Sea Coast to the east in autumn. Birds can stay for a longer time in some of the bays there. Subsequently, in Russia the total Western main population flies via the Dvuobye (over the Baydaratskaya Bay) to Northern Kazakhstan and further to the wintering areas. Thus, the eastern part of the NAO, the Baydaratskaya Bay (I - in Fig. 1) and the Lower $\mathrm{Ob}$ (Dvuobye) (II - in Fig. 1) are important territories within the flyway of Anser erythropus. The entire Western main population migrates via the Dvuobye (Jones et al., 2008).

In Russia total counts are feasible only along the coast of the Barents Sea and Kara Sea and in Dvuobye. In these regions after the breeding season, Anser erythropus gathers in large concentrations and stays for an extended period. Ground counts are impossible due to very large territories and the absence of roads, leaving aerial surveys as the best option. The use of light and ultra-light aviation gives the opportunity to make counts of a whole population occurring in a very large area within a short time frame.

We made aerial surveys and identified the key sites and main threats for Anser erythropus within this part of the flyway.

\section{Material and Methods}

Autumn surveys were carried out on 12-13 and 21-22 September 2017 in Dvuobye, on 1519 September 2017 in the NAO and on 14 and 20 September 2017 in the Baydaratskaya Bay. As the Baydaratskaya Bay is a kind of «swirl» that attracts birds migrating through Dvuobye to Kazakhstan, we planned the surveys so that we could cover the peak of Anser erythropus migration. The surveys allowed covering the majority of the migrating Anser erythropus.

The surveys were carried out using a STERKH-1S ultralight two-seater single-engine hydroplane. This model is perfect for counting waterfowl by a small number of observers (Rozenfeld et al., 2017). The total area of the territory explored was $23506 \mathrm{~km}^{2}$. The total route length was $12608 \mathrm{~km}$ (Fig. 1). The survey routes were 
plotted to sites with potentially suitable habitats previously chosen, based on topographic maps and Landsat images (Fig. 1). The flight track was recorded with a GPS Garmin Dacota 20. During the count the aircraft speed was $80-120 \mathrm{~km} / \mathrm{h}$, the flight altitude was $15-100 \mathrm{~m}$. The count was carried out in a strip of 1000-2000 m at both sides of the aircraft. We used the GPS navigator Garmin Dacota 20 to map flocks at 30-50 $\mathrm{m}$ altitudes. We photographed all birds per flock using a Canon 700D camera with $100-400 \mathrm{~mm}$ lens for mapping. To geo-reference the photographs, we used a GP-12 Canon GPS Receiver, synchronised with the camera. The photographs were subsequently referenced to track points using the free GEOSETTER software. Approaching a flock, we descended to an altitude of 10 to $20 \mathrm{~m}$ to photograph and to identify species- and proportions within the flock. In total, 8274 photographs were analysed.

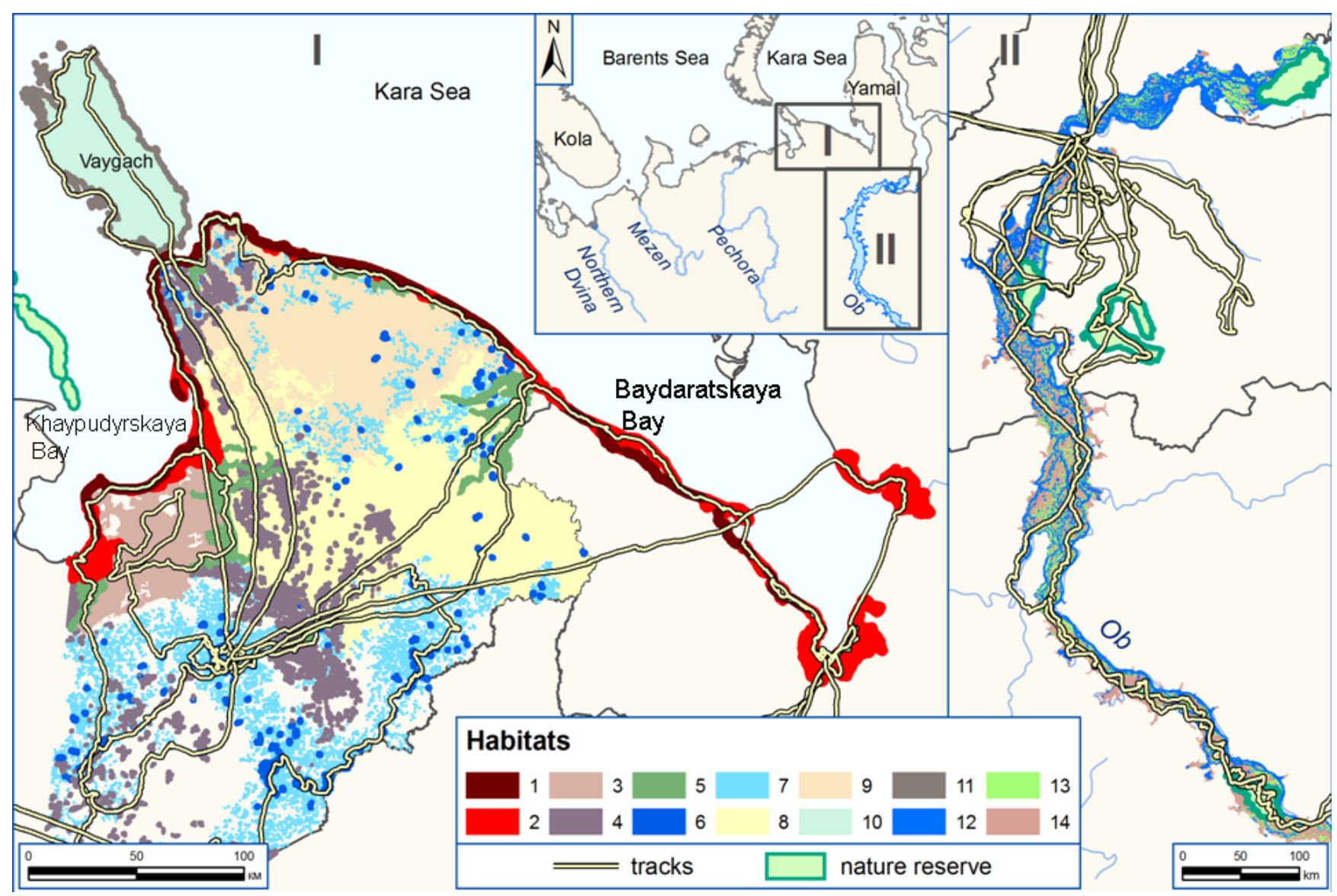

Fig. 1. The aerial survey's routes and Anser erythropus habitats selected for extrapolation of abundance based on the analysis of Landsat images. I - eastern part of NAO and Baydaratskaya Bay, II - Dvuobye, Lower Ob. Habitat designations: 1 - coast land (1 km wide from the coastline deep into the mainland) limited in the mainland part of the study area by any habitats with an access to the sea apart from marshes (total area is $412.22 \mathrm{~km}^{2}$ ); 2 - bogged littoral plains with a lot of girts, creeks, basins, lakes, flooded at high tide, with Carex-grass marsh halophytic meadows, shrubby-poaceous tundras, Eriophorum bogs (total area is $\left.1615.06 \mathrm{~km}^{2}\right) ; 3$ - transitional bogs and palsas, hillock and ridge-pool complexes, Sphagnum, shrubby-grass-Sphagnum and grass-Hypnum bogs along with areas of forb-sedge-moss tundras and a large number of lakes (total area is $2797.83 \mathrm{~km}^{2}$ ); 4 - pattern bogs, hummock-ridge bogs («aapa» type moore), transitional bogs and palsas, hillock and ridge-pool complexes, with thermokarst lakes, grass-lichen-moss and shrubby-Sphagnum bogs at the hillocks and hummock ridges, Eriophorum-CarexHypnum-acid bogs in swampy hollows (total area is $2529.73 \mathrm{~km}^{2}$ ); 5 - floodplains, bar-pitted, with numerous arms, watercourses and bayou lakes, forb-Carex meadows, often bogged, grass-moss bogs with Salix and Alnus stands at the land (total area is $1244.8 \mathrm{~km}^{2}$ ); 6 - large lakes with an area of more than $0.5 \mathrm{~km}^{2}$ (total area is $417.49 \mathrm{~km}^{2}$ ); 7 - shallow lakes (total area is 657.65 $\mathrm{km}^{2}$ ); 8 - undulating, hillocky, ridge-hillocky plains, with Salix-bushy shrubby, grass-moss tundras, bogged plains and areas of Carex-Sphagnum, Carex-Eriophorum-Hypnum bogs (total area is $12025.95 \mathrm{~km}^{2}$ ); 9 - steeply-sloping, undulating, ridgehillocky plains with typical grass-moss and shrubby-lichen-spotty-low mound tundras with small areas of Carex-Sphagnum bogs along with hillocky areas with grass-moss and stony-lichen tundras (total area is $8803.19 \mathrm{~km}^{2}$ ); 10 - Vaygach Island and small adjacent islands (total area is $\left.3252.3 \mathrm{~km}^{2}\right) ; 11$ - off shore zone (150 m wide from the coastline to the sea) around Vaygach Island and adjacent islands (total area is $106.4 \mathrm{~km}^{2}$ ); 12 - River Ob course, tributaries, and lakes in the floodplain visible at the lowest water level (total area is $4460.04 \mathrm{~km}^{2}$ ); 13 - the most elevated areas of the River Ob floodplain, levees, outliers, partly bogged, with osiers, Salix-Alnus-Betula, Pinus-Larix, Picea-Betula-Larix-Pinus forests (total area is $6739.3 \mathrm{~km}^{2}$ ); $14-$ regularly flooded part of the River Ob floodplain, very bogged, with muddy and sandy banks, temporary flooded lakes (sors), forb-Carex-poaceous, bent grass-Juncus-Carex meadows, with shrubby osiers (total area is $18072.89 \mathrm{~km}^{2}$ ). 
Estimation of the total numbers of geese in autumn 2017

We define the estimated number as the result of extrapolation of the numbers of birds counted during the aerial survey to the whole territory of potentially suitable habitats, including unsurveyed areas. Density surface modeling was used to calculate the numbers of birds (Miller et al., 2016). The method requires the partitioning of the count strip into continuous segments, and we used segments of $2 \mathrm{~km}$ in length, the area of which, respectively, was $4 \mathrm{~km}^{2}$. Calculations that require the use of geographic operators were conducted using GIS Manifold System 8.0; other data processing was performed in the Paradox 9.0 Database Management System. The calculations were performed in the dsm package version 2.2.13 (Miller et al., 2016) of the R statistical language version 3.3.2 (R Core Team, 2016). A full description of methods is given by Rozenfeld et al. (2017).

\section{Results and Discussion}

Survey of the eastern part of the Nenetsky Autonomous Okrug including the part of western coast of the Baydaratskaya Bay

The total number of Anser erythropus counted within the eastern part of NAO (including the western part of Baydaratskaya Bay within NAO borders) was 4881 individuals. The proportion of young birds in the study region was $27.3 \%(n=2292)$. Large concentrations were noted at the coast of the Khaypudyrskaya Bay and at the western coast of the Baydaratskaya Bay, especially in the estuary of the River Kara and in the northeastern part of the Yugorsky Peninsula. Small flocks of Anser erythropus were encountered on the Vaygach Island (Fig. 1, Fig. 2). Anser erythropus migrates across the study area in a wide front, often together with the other hunted goose species (Fig. 2).

Survey of the Baydaratskaya Bay within the Yamalo-Nenetsky Autonomous Okrug and in the Dvuobye

The coastal marine marshes of Baydaratskaya bay, as was shown in our 2012-2015 survey, are used by Anser erythropus as main staging sites (Rozenfeld et al., 2017; Rozenfeld \& Kirtaev, 2017). After Baydaratskaya bay survey, the next step of the migration is Dvuobye. This area is known as a very important key stopover site on a flyway scale according to data from satellite transmitter tagged birds and our previous observations (Rozenfeld \& Strelnikov, 2011; Rozenfeld et al., 2016b, 2017).

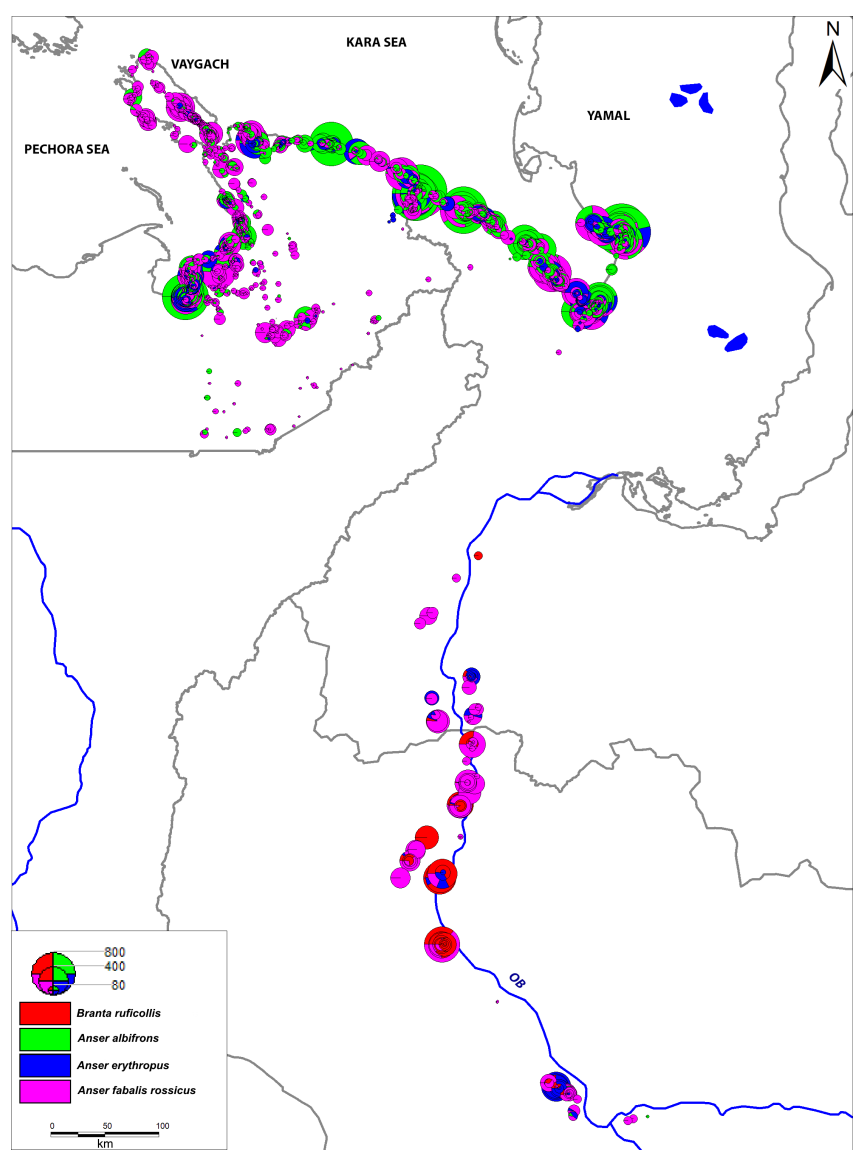

Fig. 2. Sites of encounters, number and distribution of geese in the study area.

In 2017 we counted 5190 Anser erythropus: 3699 in the Baydaratskaya Bay within YNAO and 1491 in the Dvuobye. The proportion of young birds at the autumn migration here was $31.4 \%$ $(n=3380)$.

The proportion of Anser erythropus in noted goose flocks whitin the survey area and the estimated numbers of Anser erythropus and the other geese species

The proportion of Anser erythropus in noted goose flocks was $11 \%$ (Fig. 2). The proportion of young birds $-29.4 \%(n=5672)$. The total number of counted Anser erythropus during the survey was 10 071. Extrapolation based on suitable habitat gave a total of 48581 individuals $(\mathrm{SE}=2819.9$, $\mathrm{CV}=0.058)$.

The proportion of Anser fabalis rossicus Brisson, 1760 in the mixed geese flocks amounted to $4.3 \%$. The proportion of young birds turned out to be very small: only $16.9 \%(n=272)$. The total number of registered birds was 18 818. The extrapolative number amounted to 202340 individuals $(\mathrm{SE}=14$ 439.5, $\mathrm{CV}=0.0714)$.

The flock size of Anser albifrons Scopoli, 1769 varied from separate pairs and groups to 
1500 birds. In the study period, the proportion of Anser albifrons in the noted goose flocks was $31 \%$. The proportion of young birds was $25.4 \%(n=2155)$. The number of registered birds totaled 13567 . The extrapolative number amounted to 115926 birds $(\mathrm{SE}=8076.202$, $\mathrm{CV}=0.070$ ).

Branta ruficollis Pallas, 1769 was observed only in Dvuobye. In the study period, the proportion of this species in the noted goose flocks in Dvuobye was $23.6 \%$. The proportion of young birds was only $5.5 \%(n=138)$. The number of registered birds totaled 2529. We didn't make the extrapolation of numbers as this species uses only Dvuobye as the migration route and not the whole study area.

We did not find large concentrations of Branta bernicla Linnaeus, 1758. Fifteen groups of this species were encountered in total: on the Vaygach Island, the Yugorsky Peninsula, the coast of the Khaypudyrskaya Bay, in the estuary of the River Kara and at the coast of the Baydaratskaya Bay. In total, we noted six separate flocks ranging from 22 to 250 birds, and nine small groups (2-9 birds) that we encountered in the mixted geese flocks. In total, 575 birds were registered. The proportion of Branta bernicla in the noted flocks was very small: only $1 \%$. We failed to note young birds. The late and cold spring of 2017 could have led to almost no breeding of Branta bernicla.

Branta leucopsis Linnaeus, 1758 was extremely rare and was mostly encountered at the coast of the Khaypudyrskaya Bay and in the north of the Yugorsky Peninsula. The number of birds totaled 6358. The breeding success was also extremely low: the proportion of young birds was only $11.3 \%(n=1435)$.

A big proportion of Anser erythropus in the flocks of other geese species (Fig. 2) has a negative impact on the state of the species in the areas with high intensity of autumn hunting. This presents a valid reason for limiting the autumn goose hunting at the sites of concentrations of Anser erythropus. This species stays in a separate compact groups even if it is flying with other geese or even with ducks. As $\mathrm{An}$ ser erythropus are very curious and not easy to frighten, they often get shot by ignorant hunters. In the study region, Anser erythropus forms large flocks of 50-300 birds. In such concentrations, illegal shooting can sufficiently affect the numbers.
The abundance of Anser erythropus in autumn 2017

Our survey data thus show a higher number than in the previous estimates of the Western main population made in northern Kazakhstan (Rozenfeld et al., 2016a; Cuthbert \& Aarvak, 2016; Fox \& Leafloor, 2018). These results can mean two things. First - the ground surveys can not reflect the whole picture. Second - we had the chance to «catch» the whole population in the stage of premigration concentrations in all known sites during the autumn migration. Our estimates of abundance can be regarded as a certain benchmark, on which it is necessary to rely in the future to analyse the dynamics of abundance and breeding success and distribution of Anser erythropus.

Conservation implication and recommendation

In Russia, the conservation of Anseriformes is possible through the creation of temporary hunting free zones during the hunting season. A justification for creating such zones and outlining their boundaries (by analogy with the experience derived from the countries in North America) each season must be based on data on annual waterfowl monitoring. Based on an evaluation of the habitat quality (density of birds in each habitat), data from tagged birds and the numbers in observed concentrations the Anser erythropus key sites were chosen (Fig. 2, Fig. 3). To identify key sites, the following criteria were used: (1) multiannual long-term places of stopovers for Anser erythropus, according to satellite tracking data and observations; (2) maximum concentrations. Some key territories of Anser erythropus discovered during our study, fall into currently existing specially protected natural areas. On the other hand, certain key sites where Anser erythropus temporary gather in great numbers belong to areas most frequently visited by hunters. A GIS project was launched that incorporated the main migration routes, boundaries of the key sites, places of mass bird aggregations, and sites for the observation of Anser erythropus. In these territories, waterfowl hunting has to be limited by creating protected areas or permanent waterfowl hunting free zones (hunting resources protected areas). We note that some of the key sites are a part of the wetlands included in the shadow list of the Ramsar Convention on wetlands of international importance. We also recommend carrying out annual monitoring of Anser erythropus at these sites. 


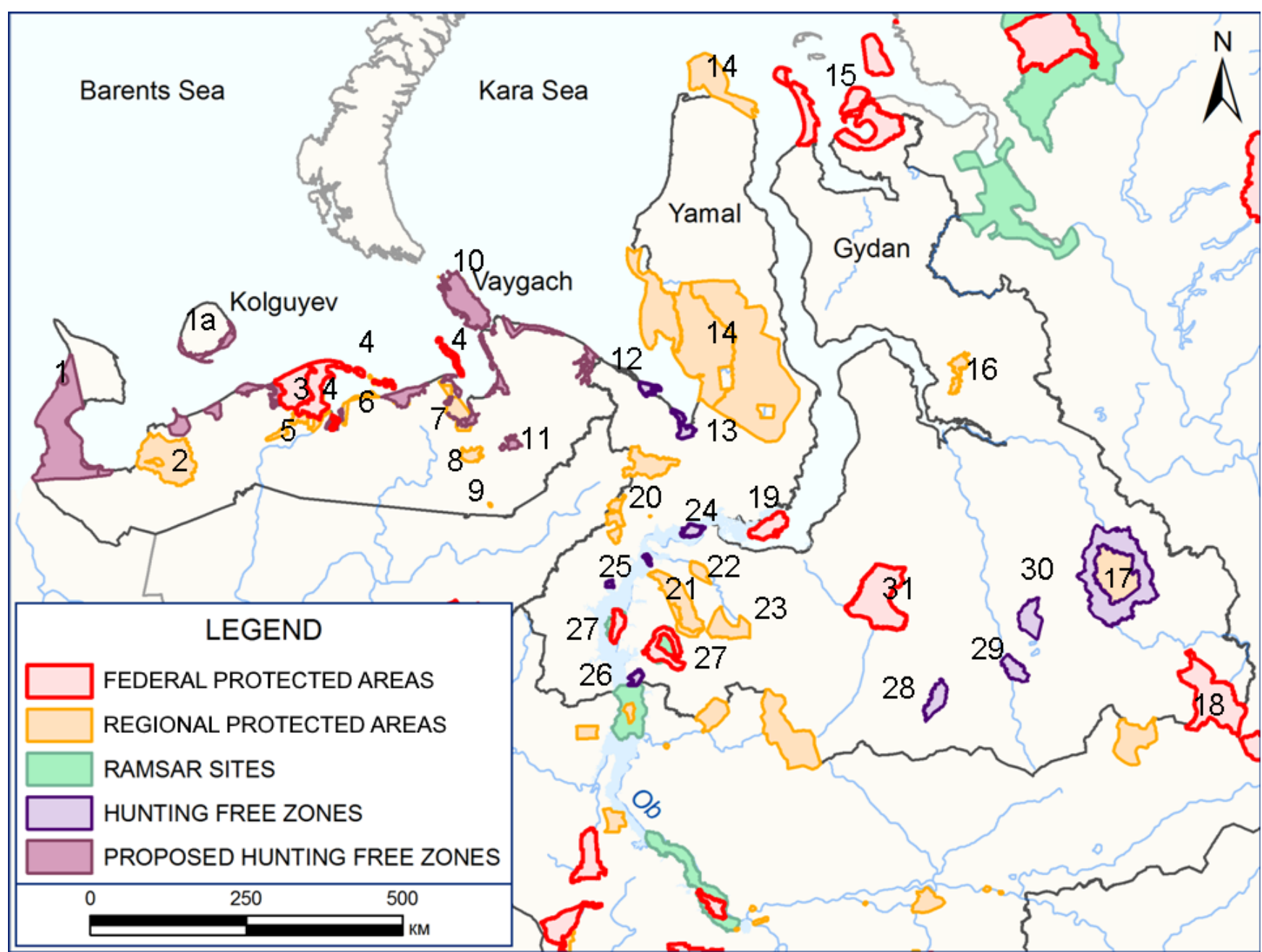

Fig. 3. Chart of key sites, existing and proposed protected areas for the Western main population of Anser erythropus in NAO and YNAO. Designations: 1 - Shoinsky State Nature Sanctuary; 1a - Spring hunting free zone «Kolguev Island» (entire island's area); 2 - Severnyi Timan Natural Park; 3 - State Nature Sanctuary «Nenetsky»; 4 - State Nature Reserve « Nenetsky»; 5 - Nizhnepechorsky State Nature Sanctuary; 6 - Pakhanchesky State Nature Sanctuary; 7 - Khaypudyrsky State Nature Sanctuary; 8 - More-Yu State Nature Sanctuary; 9 - Kamennyi Gorod Natural Monument; 10 - Vaygach State Nature Sanctuary and spring hunting free zone «Vaygach Island» (entire island's area); 11 - Vashutkinsky State Nature Sanctuary; 12 - Spring hunting free zone «Levdievskaya»; 13 - Spring hunting free zone «Baydaratskaya»; 14 - Yamalsky State Biological Sanctuary; 15 - State Nature Reserve «Gydansky»; 16 - Messo-Yakhinsky State Nature Sanctuary; 17 - Pyakolsky State Nature Sanctuary and spring hunting free zone «Pyakolskaya»; 18 - State Nature Reserve «Verkhne-Tazovsky»; 19 - State Nature Sanctuary «Nizhne-Obsky»; 20 - Polyarno-Uralsky Natural Park; 21 - Sobty-Yugansky State Nature Sanctuary; 22 - Poluysky State Nature Sanctuary; 23 - Verkhne-Poluysky State Nature Sanctuary; 24 - Spring hunting free zone «Kharposlinskaya»; 25 - Spring hunting free zone «Shuryshkarskaya»; 26 - Spring hunting free zone «Zazhimcharskaya»; 27 - State Nature Sanctuary «Kunovatsky»; 28 - Spring hunting free zone «Khanymey»; 29 - Spring hunting free zone «Ayvasedapur»; 30 - Spring hunting free zone «Chaselka»; 31 - State Nature Sanctuary «Nadymsky».

At present time, raw hydrocarbon material is transported from its sources in the Yamal Peninsula through pipelines laid on the bottom of the Baydaratskaya Bay. These large infrastructure objects also run straight across the coastal marine marshes used by Anser erythropus. Data obtained in the framework of the current study indicate that the gas exploration infrastructure in Baydaratskaya Bay has not caused any decrease of the numbers of Anser erythropus so far and exerts no negative effects on the bird's survival.

According to our data, the number of the Western main population of Anser erythropus is higher than previously estimated. It can be estimated at $48580 \pm 2820$ individuals after the breeding season.

The key sites and the main threats for the Western main population of Anser erythropus in this part of the flyway were identified. Urgent measures for conservation are proposed to the Authorities of the prospected subjects of the Russian Federation.

\section{Acknowledgments}

This study was funded by the Presidium of RAS, Program № 41 «Biodiveristy of natural systems and biological 
resources of Russia». We would like to thank the Department of Science and Innovations of the Yamalo-Nenetsky Autonomous Okrug, the Interregional Expedition Centre «Arktika», the Federation of Light and Ultra Light Aviation of Yamal «Wings of Arctic», the Department of Natural Resources and Ecology and Agriculture of the Nenetsky Autonomous Okrug, African-Eurasian Migratory Waterbird Agreement and the Bird Ringing Center of Russia (A.N. Severtsov Institute of Ecology and Evolution of RAS) for their enormous help in the realisation of our survey.

\section{References}

Aerial Survey Training Manual U.S. Fish \& Wildlife Service Migratory Bird Management, Alaska Region. Anchorage, Alaska, 2016. 54 p.

Baldassarre G.A., Bolen E.G. 2006. Waterfowl Ecology and Management. $2^{\text {nd }}$ edition. Malabar, Florida: Krieger Publishing company. $580 \mathrm{p}$.

BirdLife International. 2004. Birds in Europe: population estimates, trends and conservation status. Cambridge, UK: BirdLife International. $172 \mathrm{p}$.

Bowman T.D. 2014. Aerial Observer's Guide to North American Waterfowl. Anchorage, Alaska: US Fish and Wildlife Service. $81 \mathrm{p}$.

Cuthbert R., Aarvak T. 2016. Population Estimates and Survey Methods for Migratory Goose Species in Northern Kazakhstan. AEWA Lesser White-fronted Goose International Working Group Report Series 5: 1-96.

Fox A.D., Leafloor J.O. (Eds.). 2018. A global audit of the status and trends of Arctic and Northern Hemisphere goose populations. Akureyri, Iceland: Conservation of Arctic Flora and Fauna International Secretariat. $32 \mathrm{p}$.

IUCN. 2006. IUCN Red List of Threatened Species. A Global Species Assessment. Gland, Switzerland: IUCN. $191 \mathrm{p}$.

Jones T., Martin K., Barov B., Nagy S. 2008. International Single Species Action Plan for the Conservation of the Western Palearctic Population of the Lesser Whitefronted Goose Anser erythropus. AEWA Technical Series 36: 1-130.

Kerbes R.H., Meeres K.M., Alisauskas R.T. 2009. Surveys of nesting Lesser Snow Geese and Ross's Geese in Arctic Canada, 2002-2009. In: Arctic Goose Joint Venture Special Publication. Ottawa, Ontario: U.S. Fish and Wildlife service, Washington D.C. and Canadian Wildlife Service. 56 p.
Miller D.L., Rexstad E., Burt L., Bravington M.V., Hedley S. 2016. dsm: Density Surface Modeling of Distance Sampling Data. In: $R$ package version 2.2.13. Available from: https://CRAN.R-project.org/package=dsm

Platte R.M. 1987. Standard operating procedure for aerial waterfowl breeding ground populations and habitat surveys in North America. Ottawa, Ontario: U.S. Fish and Wildlife service, Washington D.C. and Canadian Wildlife Service. $51 \mathrm{p}$.

Poyarkov N.D., Hodges J., Eldridge V. 2000. Atlas of the distribution of birds in the coastal tundras of northeast Asia (based on aerial surveys 1993-1995). Moscow: Wildlife Conservation Centre. 88 p. [In Russian]

R Core Team. 2016. R: A language and environment for statistical computing. Vienna, Austria: R Foundation for Statistical Computing. Available from: https://www.R-project.org/

Rozenfeld S., Strelnikov E. 2011. Survey of Lesser Whitefronted Goose Anser erythropus in lower Ob River, Russia in autumn 2010. NOF-report 2011-3: 1-25.

Rozenfeld S., Kirtaev G. 2017 Monitoring and identification of key sites of Lesser White-fronted Goose (Anser erythropus) in Baydaratskaya Bay and adjacent territories. Goose Bulletin 22: 17-25.

Rozenfeld S.B., Timoshenko A.Yu., Zuban I.A. 2016a. Monitoring of goose populations at their Northern Kazakhstan migration stopover as the basis for the development of protection measures and wise use. Casarca 19(1): 94-129. [In Russian]

Rozenfeld S., Kirtaev G., Soloviev M., Rogova N., Ivanov M. 2016b. The results of autumn counts of Lesser White-fronted Goose and other geese species in the $\mathrm{Ob}$ valley and White-sea-Baltic flyway in September 2015. Goose Bulletin 21: 12-32.

Rozenfeld S.B., Soloviev M.Yu., Kirtaev G.V., Rogova N.V., Ivanov M.N. 2017. Estimation of the Spatial and Habitat Distribution of Anseriformes in the Yamal-Nenets and Khanty-Mansi Autonomous Regions (Experience from the Use of Ultralight Aircrafts). Biology Bulletin 44(8): 960-979. DOI: 10.1134/S1062359017080143

U.S. Fish \& Wildlife Service. 2012. Waterfowl population status, 2012. Washington, DC: U.S. Department of the Interior. $79 \mathrm{p}$.

Vinogradov V.G., Morozov V.V. 2001. Lesser White-fronted Goose. In: V.I. Danilov-Danilyan (Ed.): Red Data Book of Russian Federation (Animals). Moscow: AST-Astrel. P. 399-401. [In Russian] 


\title{
РЕЗУЛЬТАТЫ АВИАУЧЕТОВ ЗАПАДНОЙ ПОПУЛЯЦИИ ANSER ERYTHROPUS (ANSERINI) В ПЕРИОД ОСЕННЕЙ МИГРАЦИИ В РОССИИ В 2017 ГОДУ
}

\author{
С. Б. Розенфель ${ }^{1,2, *}$, Г. В. Киртаев ${ }^{3}$, Н. В. Рогова ${ }^{3, * *}$, М. Ю. Соловьев ${ }^{4, * * *}$ \\ ${ }^{1}$ Институт проблем экологии и эволюиии имени А.Н. Севериова РАН, Россия \\ *e-mail: rozenfeldbro@mail.ru \\ ${ }^{2}$ Государственный природныии заповедник «Гыданский», Россия \\ ${ }^{3}$ Рабочая группа по гусеобразным Северной Евразии, Россия \\ **e-mail: nrogova@gmail.com \\ ${ }^{4}$ Московский государственный университет имени М.В. Ломоносова, Россия \\ ***e-mail:mikhail-soloviev@yandex.ru
}

\begin{abstract}
В сентябре 2017 г. проведены авиаучеты пискульки (Anser erythropus) западной популяции и других видов гусей и казарок в восточной части Ненецкого автономного округа, в Байдарацкой губе и в Двуобье. Экстраполяционная оценка численности пискульки методом генерализованных аддитивных моделей составила $48580 \pm 2820$ особей. Полученные данные по численности пискульки показали, что она выше, чем предполагалось ранее по результатам учетов в северном Казахстане (30 000-34 000 особей). Кроме того, определен успех размножения, выявлены основные угрозы и ключевые места в районе работ. В Администрации Ненецкого и Ямало-Ненецкого автономных округов направлены конкретные предложения по созданию зон покоя водоплавающей дичи на выявленных ключевых местах.
\end{abstract}

Ключевые слова: авиаучеты, мониторинг, Ненецкий автономный округ, пискулька, Ямало-Ненецкий автономный округ 